\title{
Description of the karyotype of Rhagomys rufescens Thomas, 1886 (Rodentia, Sigmodontinae) from Southern Brazil Atlantic forest
}

André Filipe Testoni ${ }^{1,5}$, Sérgio Luiz Althoff ${ }^{2}$, André Paulo Nascimento ${ }^{3}$, Francisco Steiner-Souza ${ }^{4}$ and Ives José Sbalqueiro ${ }^{1}$

${ }^{1}$ Laboratório de Citogenética Animal, Departamento de Genética, Universidade Federal do Paraná,Curitiba, PR, Brazil.

${ }^{2}$ Laboratório de Biologia Animal, Departamento de Ciências Naturais, Fundação Universidade Regional de Blumenau, Blumenau, SC, Brazil.

${ }^{3}$ Laboratório de Genética, Departamento de Ciências Naturais, Fundação Universidade Regional de Blumenau, Blumenau, SC, Brazil.

${ }^{4}$ Programa de Pós-Graduação em Biologia Animal, Departamento de Zoologia,

Universidade Federal do Rio Grande do Sul, Porto Alegre, RS, Brazil.

${ }^{5}$ Programa de Pós-Graduação em Genética, Departamento de Genética, Universidade Federal do Paraná, Curitiba, PR, Brazil.

\begin{abstract}
Rhagomys rufescens (Rodentia: Sigmodontinae) is an endemic species of the Atlantic forest from Southern and Southeastern Brazil. Some authors consider Rhagomys as part of the tribe Thomasomyini; but its phylogenetic relationships remain unclear. Chromosomal studies on eight specimens of Rhagomys rufescens revealed a diploid number of $2 n=36$ and a number of autosome arms $F N=50$. GTG, CBG and Ag-NOR banding and $\mathrm{CMA}_{3} / \mathrm{DAPI}$ staining were performed on metaphase chromosomes. Eight biarmed and nine acrocentric pairs were found in the karyotype of this species. The $\mathrm{X}$ and $\mathrm{Y}$ chromosomes were both acrocentric. Most of the autosomes and the sex chromosomes showed positive C-bands in the pericentromeric region. The $\mathrm{X}$ chromosome showed an additional heterochromatic block in the proximal region of the long arm. Nucleolus organizer regions (NORs) were located in the pericentromeric region of three biarmed autosomes (pairs 4, 6 and 8) and in the telomeric region of the short arm of three acrocentrics (pairs 10,12 and 17). $\mathrm{CMA}_{3}$ /DAPI staining produced fluorescent signals in many autosomes, especially in pairs 4,6 , and 8 . This study presents cytogenetic data of Rhagomys rufescens for the first time.
\end{abstract}

Key words: Rhagomys rufescens, Thomasomyini, Rodentia, Atlantic forest, karyotype.

Received: October 9, 2009; Accepted: March 26, 2010.

The subfamily Sigmodontinae (Wagner 1843) comprises 74 genera and 377 species (Musser and Carleton, 2005) and includes predominantly South American Cricetidae rodents, such as Rhagomys rufescens. This species is endemic to the Atlantic forest from Southern and Southeastern Brazil, and has already been reported in Rio de Janeiro, Minas Gerais, São Paulo, Espírito Santo and Santa Catarina (Moojen, 1952; Emmons and Feer, 1997; Eisenberg and Redford, 1999; Nowak, 1999; Percequillo et al., 2004; Pinheiro et al., 2004; Metzger et al., 2006; Pardini and Umetzu, 2006; Steiner-Souza et al., 2008). The first record of R. rufescens in Southern Brazil was recently

Send correspondence to Ives José Sbalqueiro. Laboratório de Citogenética Animal, Departamento de Genética, Centro Politécnico, Universidade Federal do Paraná, Jardim das Américas, 81531-990 Curitiba, PR, Brazil. E-mail: ivesjs@ufpr.br. obtained at the Parque Natural Municipal Nascentes do Garcia (PNMNG), in the state of Santa Catarina (SteinerSouza et al., 2008).

Rhagomys rufescens was originally described as Hesperomys rufescens, based on a female collected in Rio de Janeiro, southeastern Brazil. In the beginning of the $20^{\text {th }}$ century, Thomas collected another specimen from an unknown locality, which was used for the description of the genus Rhagomys (Thomas 1917) (Percequillo et al., 2004). A second species, Rhagomys longilingua, was recently described based on a male collected in the Montana forests in southern Peru (Luna and Patterson, 2003), that was later found to reach as far as Bolivia (Villalpando et al., 2006).

Rhagomys is considered incertae sedis (Reig, 1980, 1984; McKenna and Bell, 1997; Smith and Patton, 1999; Musser and Carleton, 2005) or a "plesiomorphic Neotropical muroid", according to Voss (1993) and Steppan (1995), 
and there is no consensus regarding its tribal position (Percequillo et al., 2004). Nevertheless, some authors included Rhagomys in the tribe Thomasomyini based on morphological characters (Pacheco, 2003) or on nuclear IRBP gene sequences (D'Elia et al., 2006, 2007). Cytogenetic studies on species of Thomasomyini have shown significant variation both in diploid number $(2 \mathrm{n}=20-82)$ and in the number of autosome arms (FN = 34-114) (Table 1). The species in Table 1 are grouped in "Andean" Thomasomyini, which includes genera with a predominantly Andean distribution (sensu Pacheco, 2003), and "Endemic Atlantic" Thomasomyini, an informal group named by Oliveira and Bonvicino (2002).

The objective of this study was to describe the karyotype of Rhagomys rufescens from southern Brazil after conventional and $\mathrm{CMA}_{3} / \mathrm{DAPI}$ staining, and GTG, CBG and Ag-NOR banding. The chromosomal data presented in this work can provide additional information for studies on both taxonomic and phylogenetic relationships.

Eight specimens (five males and three females) were analyzed. They were captured at PNMNG, at "Mono" locality $\left(27^{\circ} 02 ' 59^{\prime}\right.$ ' S, $49^{\circ} 08^{\prime} 57^{\prime}$ ' W), in Indaial city, in the state of Santa Catarina, southern Brazil. This park is now part of Parque Nacional da Serra do Itajaí (PNSI) (Figure 1). The animals were caught in Sherman traps placed at $3 \mathrm{~m}$ from the ground, according to Kierulff et al. (1991), with adaptations.

Chromosomes were obtained directly from bone marrow according to the method of Ford and Hamerton (1956), modified by Sbalqueiro and Nascimento (1996). Conventional Giemsa staining (5\%) was used to determine diploid number (2n), chromosomal morphology and the number of autosomal arms (FN). At least 20 metaphase plates per individual were examined. GTG, CBG and Ag-NOR banding were performed according to Seabright (1971), Sumner (1972), and Howell and Black (1980), respectively. Chromomycin A3 ( $\left.\mathrm{CMA}_{3}\right)$, and 4,6-diamidino-2phenylindole (DAPI) were used according to Schweizer (1976). Chromosomes were classified as metacentric (M), submetacentric (SM), and acrocentric (A).

Skins and skulls of specimens were deposited at the Coleção Zoológica da Fundação Universidade Regional de Blumenau (CZFURB), in Blumenau, State of Santa Catarina, Brazil.

Analyses after conventional staining showed $2 \mathrm{n}=36$ and $\mathrm{FN}=50$ in all specimens (Figure $2 \mathrm{a}$ ), with five metacentric pairs (1, 3, 6 and 8), three submetacentric (pairs 2, 4 and 5) and nine acrocentric pairs (pairs 9 to 17), decreasing gradually in size. The $\mathrm{X}$ chromosomes were acrocentric, indistinguishable from pair 9, whereas the Y chromosome was also acrocentric and similar in size to pair 10. All chromosome pairs, including the sex chromosomes, could be identified after G-banding. The X chromosome showed two positive bands in the medium portion of the long arm and the Y chromosome had one proximal band in the long arm (Figure 2b).

C-banding revealed pericentromeric constitutive heterochromatic blocks in most autosomes and also in the sex chromosomes. An additional interstitial C-band was present in the proximal region of the long arm of the $\mathrm{X}$ chromosome (Figure 2c).

NORs were detected in the pericentromeric region of pairs 4, 6 and 8, and in the telomeric region of the short arm of acrocentric pairs 10, 12 and 17 (Figure 2d). Two to twelve NORs were observed, with a mean of $7.33 \pm 3.19$ per cell $(\mathrm{N}=39)$.

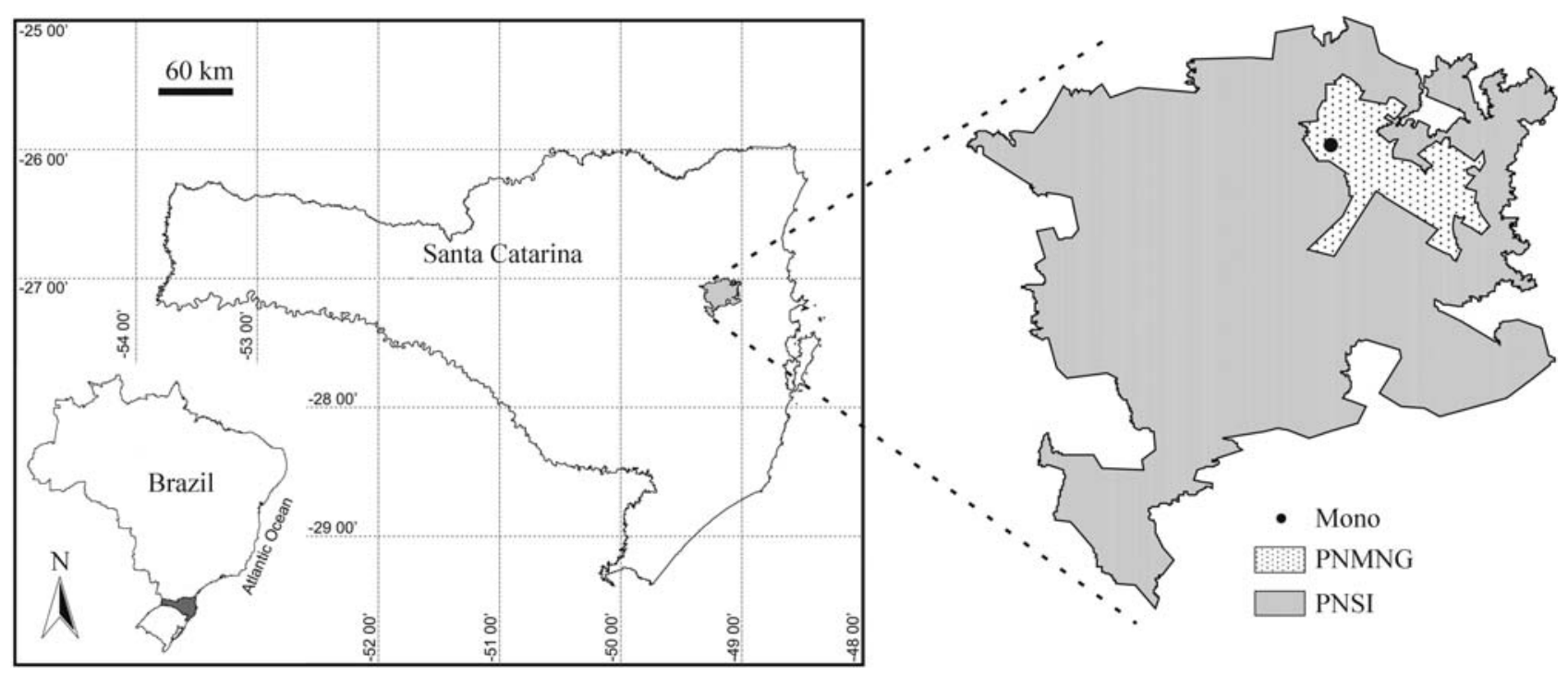

Figure 1 - "Mono" locality, data collection site of specimens at Parque Natural Municipal Nascentes do Garcia (PNMNG), part of Parque Nacional Serra do Itajaí (PNSI), state of Santa Catarina, Southern Brazil. 
Table 1 - Diploid numbers (2n) and number of autosome arms (FN) of Thomasomyini species.

\begin{tabular}{|c|c|c|c|}
\hline Species & $2 n$ & FN & Authors \\
\hline \multicolumn{4}{|l|}{ "Andean" Thomasomyini species } \\
\hline Aepeomys fuscatus & 54 & 62 & Gardner and Patton (1976) \\
\hline Aepeomys lugens & 28 & 48 & Aguilera et al. (2000) \\
\hline Aepeomys lugens & 44 & 46 & Gómez-Laverde et al. (1997) \\
\hline Aepeomys sp. & 44 & 46 & Aguilera et al. (1994) \\
\hline Aepeomys reigi & 44 & 46 & Ochoa et al. (2001) \\
\hline Rhipidomys cearanus & 44 & - & Zanchin et al. (1992a) \\
\hline Rhipidomys latimanus & 44 & 48 & Gardner and Patton (1976) \\
\hline Rhipidomys leucodactylus & 44 & 48 & Zanchin et al. (1992a) \\
\hline Rhipidomys leucodactylus & 44 & 48 & Andrades-Miranda et al. (2002) \\
\hline Rhipidomys leucodactylus cytotype 1 & 44 & 52 & Andrades-Miranda et al. (2002) \\
\hline Rhipidomys mastacalis & 44 & 74 & Zanchin et al. (1992a) \\
\hline Rhipidomys mastacalis cytotype 1 & 44 & 80 & Andrades-Miranda et al. (2002) \\
\hline Rhipidomys mastacalis cytotype 2 & 44 & 76 & Andrades-Miranda et al. (2002) \\
\hline Ripidomys cf. mastacalis & 44 & 52 & Silva and Yonenaga-Yassuda (1999) \\
\hline Rhipidomys nitela & 48 & 68 & Andrades-Miranda et al. (2002) \\
\hline Rhipidomys sclateri & 44 & 48 & Aguilera et al. (1994) \\
\hline Rhipidomys sp. & 44 & 48 & Svartman and Almeida (1993) \\
\hline Rhipidomys sp. & 44 & 49 & Svartman and Almeida (1993) \\
\hline Rhipidomys sp. & 44 & 50 & Zanchin et al. (1992a) \\
\hline Rhipidomys sp. A & 44 & 61 & Silva and Yonenaga-Yassuda (1999) \\
\hline Rhipidomys sp. B & 50 & 71,72 & Silva and Yonenaga-Yassuda (1999) \\
\hline Thomasomys andersoni & 44 & 42 & Salazar-Bravo and Yates (2007) \\
\hline Thomasomys aureus & 44 & 42 & Gardner and Patton (1976) \\
\hline Thomasomys kalinowskii & 44 & 44 & Gardner and Patton (1976) \\
\hline Thomasomys laniger & $\begin{array}{l}42 \\
40\end{array}$ & $\begin{array}{l}40 \\
40\end{array}$ & $\begin{array}{l}\text { Aguilera et al. (2000) } \\
\text { Gómez-Laverde et al. (1997) }\end{array}$ \\
\hline Thomasomys monochromos & 42 & 42 & Gardner and Patton (1976) \\
\hline Thomasomys niveipes & 24 & 42 & Gomez-Laverde et al. (1997) \\
\hline Thomasomys notatus & 44 & 44 & Gardner and Patton (1976) \\
\hline Thomasomys sp. & 44 & 42 & Gardner and Patton (1976) \\
\hline Thomasomys taczanowskii & 44 & 44 & Gardner and Patton (1976) \\
\hline Thomasomys vestitus & 44 & 42 & Aguilera et al. (2000) \\
\hline \multicolumn{4}{|c|}{ "Endemic Atlantic" Thomasomyini species } \\
\hline Delomys collinus & 82 & 86 & Bonvicino and Geise (1995) \\
\hline Delomys dorsalis & 82 & 80 & Zanchin et al. (1992b) \\
\hline Delomys sublineatus & 72 & 90 & Zanchin et al. (1992b) \\
\hline Phaenomys ferrugineus & 78 & 114 & Bonvicino et al. (2001) \\
\hline Juliomys ossitenuis & 20 & 36 & Costa et al. (2007) \\
\hline Juliomys pictipes & 36 & 34 & Bonvicino and Otazu (1999) \\
\hline Juliomys rimofrons & 20 & 34 & Oliveira and Bonvicino (2002) \\
\hline Juliomys sp. & 32 & 48 & Paresque et al. (2009) \\
\hline \multicolumn{4}{|l|}{ "Other" Thomasomyini species } \\
\hline Abrawayaomys ruschii & 58 & - & Pereira et al. (2008) \\
\hline Andinomy edax & 56 & 56 & Spotorno et al. (2001) \\
\hline Irenomys tarsalis & 64 & 98 & Ojeda et al. (2004) \\
\hline Rhagomys rufescens & 36 & 50 & Present report \\
\hline Wiedomys cerradensis & 60 & 88 & Gonçalves et al. (2005) \\
\hline Wiedomys pyrrhorhinos & 62 & 86 & Maia and Langguth (1981) \\
\hline
\end{tabular}


a

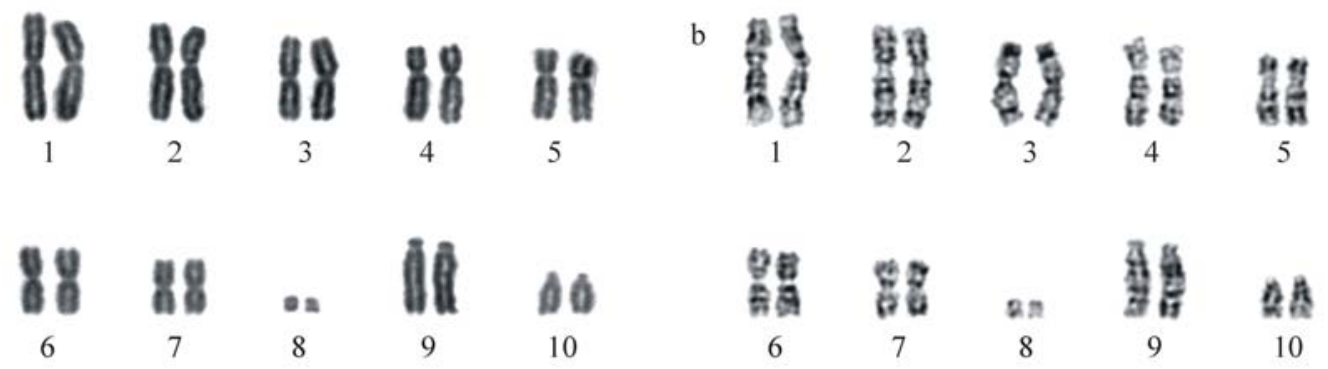

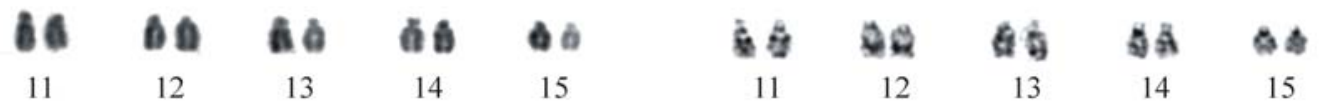
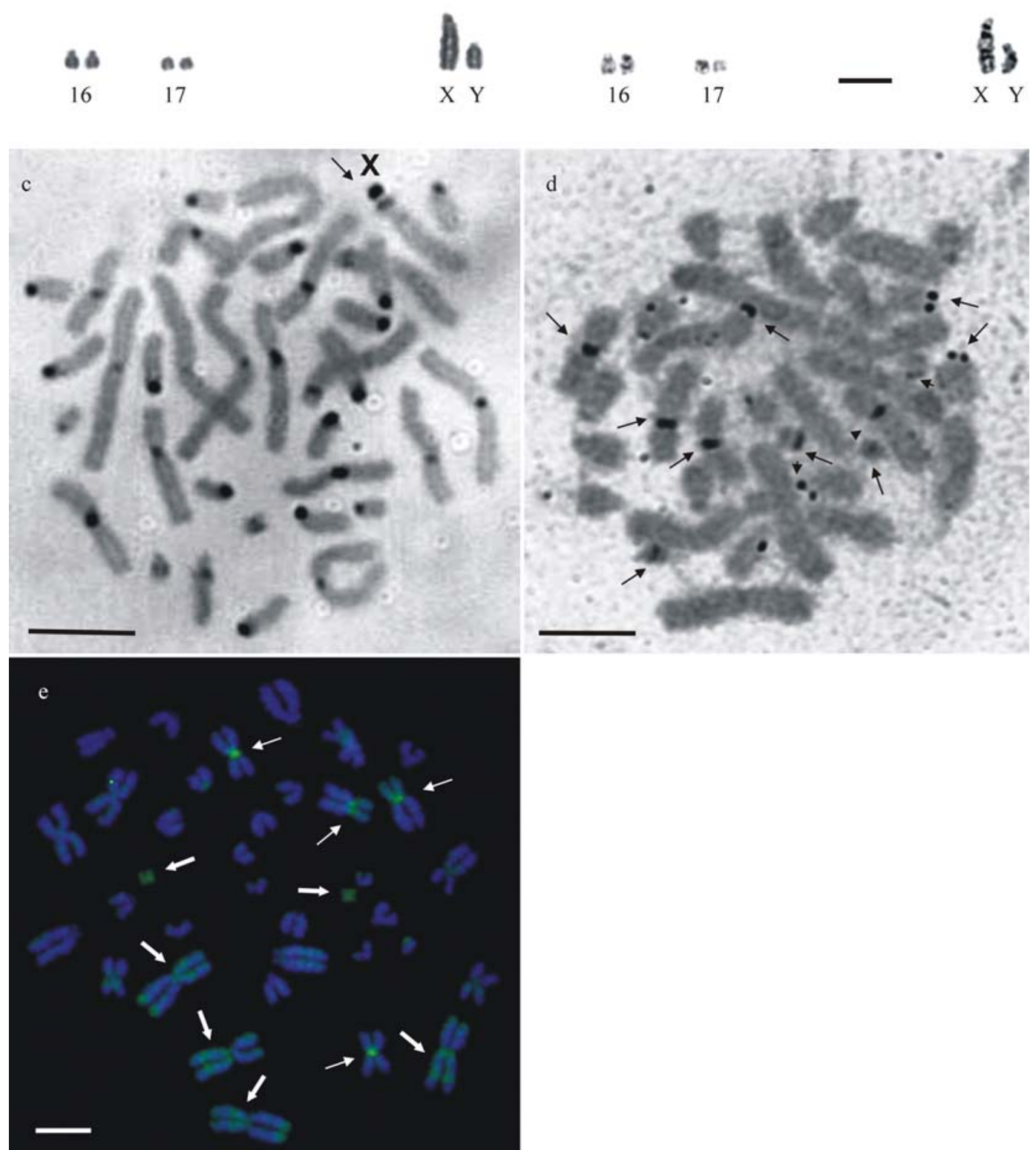

Figure 2 - Karyotype of Rhagomys rufescens (male) after (a) conventional staining and (b) G-banding. Bar = 2,5 $\mu$ m. (c) Metaphase of Rhagomys rufescens after C-banding. The arrow points to the $\mathrm{X}$ chromosome. (d) Metaphase after Ag-NOR staining. The arrows point to the nucleolus organizing regions. (e) Metaphase after $\mathrm{CMA}_{3} / \mathrm{DAPI}$ staining. The arrows point to the chromosomes with intense fluorescent $\mathrm{CMA}_{3}$ signals in the "p" and "q" arms (thick arrow) and pericentromeric region (thin arrow). 
The double staining with the GC- and AT-specific fluorochromes, $\mathrm{CMA}_{3}$ and DAPI, respectively, showed intense fluorescent $\mathrm{CMA}_{3}$ signals in the pericentromeric region of pairs 4 and 6 , and throughout the length of pair 8 . Less intense signals were observed in other pairs (Figure 2e).

Rhagomys is a polytypic genus composed by $R$. longilingua and R. rufescens. After comparative morphological analyses, Pacheco (2003) considered it monophyletic, although the two forms show a discontinuous distribution: $R$. longilingua can be found in Peru and Bolivia, whereas $R$. rufescens occurs in southern and southeastern Brazil. The phylogenetic relationships of this genus with other Sigmodontinae are controversial and uncertain and it has been previously included in different tribes of this subfamily.

Pacheco (2003) compared morphological characters of $R$. rufescens to those of various species of Sigmodontinae. This author suggested a phylogenetic relationship with the tribe Thomasomyini: Abrawayaomys, Aepeomys, Chilomys, Delomys, Juliomys, Phaenomys, Rhipidomys, Thomasomys (including Erioryzomys and Inomys), Wiedomys, and Wilfredomys. R. rufescens appeared as a sister group of Abrawayaomys ruschii or within the "Andean" Thomasomyine group (Thomasomys, Aepeomys, Chilomys and Rhipidomys).

After analyses of the nuclear IRBP (Interphotoreceptor Retinoid Binding Protein) gene sequences, D'Elia et al. (2006) suggested grouping Rhagomys longilingua with the Thomasomyini species as a sister-group of Thomasomys and as part of a larger clade that also includes Aepeomys and Rhipidomys.

On the other hand, Percequillo et al. (2004), based on mitochondrial cytochrome B sequences, concluded that the position of $R$. rufescens within Sigmodontinae was uncertain and that Rhagomys was either closely associated to Andinomys, followed by a Thomasomys-Rhipidomys group, or closer to Juliomys, followed by Andinomys.

Therefore, all these studies suggested a phylogenetic relationship of Rhagomys with Thomasomyini species. So far, cytogenetic data have shown a significant variation in both diploid number $(2 \mathrm{n}=20-82)$ and FN (34-114) (Zanchin et al., 1992b Bonvicino and Geise, 1995; Bonvicino and Otazu, 1999; Oliveira and Bonvicino, 2002; Costa et al., 2007). Nevertheless, most species presented $2 \mathrm{n}=44$ and a predominance of acrocentric chromosomes, which were the cases of the species of Rhipidomys and Thomasomys (Table 1), possibly a sister group of Rhagomys (Pacheco, 2003; Percequillo et al., 2004, D'Elia et al., 2006). These results differ from our chromosome data of Rhagomys rufescens $(2 \mathrm{n}=36$ and $\mathrm{FN}=50)$, which had eight biarmed and nine acrocentric autosomal pairs.

The cytogenetic data of Rhagomys rufescens $(2 \mathrm{n}=36$ and $\mathrm{FN}=50$ ) described herein are the first for this genus. Pair 9 and the $\mathrm{X}$ chromosome were undistinguishable after conventional staining because of their similar sizes and morphologies. However, GTG and CBG banding patterns showed significant differences allowing their individual identification. The two interstitial G-bands in the long arm of the X chromosome, characteristic of mammalian X chromosomes (Pathack and Stock, 1974), could be observed. Furthermore, an additional block of interstitial constitutive heterochromatin was present in the proximal region of the long arm of $\mathrm{X}$ chromosome, whereas pair 9 only presented a pericentromeric heterochromatic block. The Y chromosome, which is almost completely heterochromatic in many species of South-American rodents (Sbalqueiro et al. 1991; Andrades-Miranda et al., 2001), only presented a positive $\mathrm{C}$-band in the pericentromeric region in Rhagomys rufescens.

After double fluorochrome staining, CMA3-positive and DAPI-negative signals were present in sites coincident with all AgNORs. The correlation of NORs with GC-rich sites is relatively common among vertebrates (Schmid, 1982; Amemiya and Gold, 1986; Artoni et al., 1999, among others), although the reverse correlation is not always valid. Additional GC-rich sites were also observed, mainly in the first three chromosome pairs. These sites were euchromatic domains adjacent to G-bands, known to correspond to GCrich isochores (R-bands), especially close to the telomeric region (Bernardi, 1993; Holmquist and Ashley, 2006). However, several authors suggested the use of the silver staining technique in conjunction with FISH (rDNA probes) to confirm the number and location of NORs (Santos et al., 2001; Fagundes et al., 2003; Leite-Silva et al., 2003).

The comparison of the chromosome data presented herein to those of the other Thomasomyini species mentioned above does not allow to determine the taxonomic relationship of Rhagomys rufescens. The scarcity of cytogenetic data of a larger number of species and the lack of techniques that could show more details about chromosome structure makes further taxonomic analysis a difficult task. It is evident that several chromosome rearrangements have contributed to the karyotypic variability observed in Thomasomyini. Complementary data obtained from differential staining associated with FISH techniques, such as ZOO-FISH (Hass et al., 2008), is necessary for clarifying the mechanisms of karyotypic evolution in this group, and hence contribute to determine the taxonomic position of this genus. The data reported herein are important as a first characterization of the chromosome complement of $R$. rufescens because it allows the identification of some primary features of its karyotype.

\section{Acknowledgments}

The authors would like to thank Dr. Iris Hass (UFPR), Dr. Edivaldo Herculano Correa de Oliveira (UFPA), Dr. Rafael Noleto (UFPR), and Dr. Geraldo Moretto (FURB) for their critical reading of the manuscript; Rafael Pasold 
and Esmeralda Dávida Ferreira da Silva for their help with the fieldwork; Guilherme Pereira Rabelo for technical assistance; Instituto Parque das Nascentes (IPAN) and IBAMA (Instituto Brasileiro do Meio Ambiente e dos Recursos Naturais Renováveis) for logistic support with data collection at the Parque Natural Municipal Nascentes do Garcia (PNMNG).

\section{References}

Aguilera M, Pérez-Zapata M, Martino A, Barros MA and Patton J (1994) Karyosystematics of Aepeomys and Rhipidomys (Rodentia, Cricetidae). Acta Cient Venez 48:247-248.

Aguilera M, Pérez-Zapata A, Achoa J and Soriano P (2000) Karyology of Aepeomys and Thomasomys (Rodentia, Muridae) from the Venezuelan Andes. J Mammal 8:52-58.

Amemiya CT and Gold JR (1986) Chromomycin A3 stains nucleolus organizer regions of fish chromosomes. Copeia 1986:226-231.

Andrades-Miranda J, Oliveira LFB, Lima-Rosa CAV, Nunes AP, Zanchin NIT and Mattevi MS (2001) Chromosomes studies in seven species of the genus Oligoryzomys (Rodentia, Sigmodontinae) from Brazil. J Mammal 82:1080-1091.

Andrades-Miranda J, Oliveira LFB, Lima-Rosa CAV, Sana DA, Nunes AP and Mattevi MS (2002) Genetic studies in representatives of genus Rhipidomys (Rodentia, Sigmodontinae) from Brazil. Acta Theriol 47:125-135.

Artoni RF, Molina WF, Bertollo LAC and Galetti Jr PM (1999) Heterochromatin analysis in the fish species Liposarcus anisitsi (Siluriformes) and Leporinus elongatus (Characiformes). Genet Mol Biol 22:1-6.

Bernardi G (1993) The vertebrate genome: Isochores and evolution. Mol Biol Evol 10:186-204.

Bonvicino CR and Geise L (1995) Taxonomic status of Delomys dorsalis collinus Thomas, 1917 (Rodentia, Cricetidae) and description of a new karyotype. Mamm Biol 60:124-127.

Bonvicino CR and Otazu I (1999) The Wilfredomys pictipes (Rodentia, Sigmodontinae) karyotype with comments on the karyosystematics of Brazilian Thomasomyini. Acta Theriol 44:329-332.

Bonvicino CR, Oliveira JA, D'Andrea OS and Carvalho RW (2001) The endemic Atlantic Forest rodent Phaenomys ferrugineus (Thomas, 1894) (Sigmodontinae): New data on its morphology and karyology. Bol Mus Nac 467:1-12.

Costa LP, Pavan SE, Leite YLR and Fagundes V (2007) A new species of Juliomys (Mammalia, Rodentia, Cricetidae) from the Atlantic forest of southeastern Brazil. Zootaxa 1463:2137.

D'Elia G, Luna L, Gonzalez EM and Patterson BD (2006) On the Sigmodontinae radiation (Rodentia, Cricetidae): An appraisal of the phylogenetic position of Rhagomys. Mol Phylogenet Evol 38:558-564.

D’Elia G, Pardiñas UFJ, Teta P and Patton JL (2007) Defination and diagnosis of new tribe os Sigmodontinae rodents (Cricetidae, Sigmodontinae), and a revised classification of the subfamily. Gayana 71:187-194.

Eisenberg JF and Redford KH (1999) Mammals of the Neotropics: The Central Neotropics. v. 3. University of Chicago Press, Chicago, 609 pp.
Emmons LH and Feer F (1997) Neotropical Rainforest Mammals: A Field Guide. 2nd edition. University of Chicago Press, Chicago, 307 pp.

Fagundes V, Christoff AU, Amaro-Ghilard RC, Scheibler DR and Yonenaga-Yassuda Y (2003) Multiple interstitial ribosomal sites (NORs) in the Brazilian squirrel Sciurus aestuans ingrami (Rodentia, Sciuridae) with $2 \mathrm{n}=40$ : An overview of Sciurus cytogenetics. Genet Mol Biol 26:253-257.

Ford CE and Hamerton JL (1956) A colchicine hypotonic citrate squash sequence for mammalian chromosome. Stain Technol 31:247-251.

Gardner AL and Patton JL (1976) Karyotypic variation in oryzomyine rodents (Cricetidae) with comments on chromosomal evolution in the Neotropical cricetine complex. Occas Pap Mus Zool 49:1-48.

Gomez-Laverde M, Montenegro-Diaz O, Lopez-Arevalo H, Cadena A and Bueno ML (1997) Karyology, morphology, and ecology of Thomasomys laniger and T. niveipes (Rodentia) in Colombia. J Mammal 78:1282-1289.

Gonçalves PR, Almeida FC and Bonvicino CR (2005) A new species of Wiedomys (Rodentia, Sigmodontinae) from Brazilian Cerrado. Mamm Biol 70:46-60.

Hass I, Sbalqueiro IJ and Müller S (2008) Chromosomal phylogeny of four Akodontini species (Rodentia, Cricetidae) from Southern Brazil established by ZOO-FISH using Mus musculus (Muridae) painting probes. Chromosome Res $16: 75-88$

Holmquist GP and Ashley T (2006) Chromosome organization and chromatin modification: Influence on genome function and evolution. Cytogenet Genome Res 114:96-125.

Howell WM and Black DA (1980) Controlled silver staining of nucleolus organizer region with protective colloidal developer: A 1-step method. Experientia 36:1014-1015.

Kierulff MC, Stalling JR and Sabato EL (1991) A method to capture the bamboo rat (Kannabateomys amblyonyx) in bamboo forests. Mammalia 55:633-635.

Leite-Silva C, Santos N, Fagundes V, Yonenaga-Yassuda Y and de Souza MJ (2003) Karyotypic characterization of the bat species Molossus ater, M. molossus and Molossops planirostris (Chiroptera, Molossidae) using FISH and banding techniques. Hereditas 138:94-100.

Luna L and Patterson B (2003) A remarkable new mouse (Muridae, Sigmodontinae) from southeastern Peru: With comments on the affinities of Rhagomys rufescens (Thomas, 1886). Fieldiana Zool 101:1-24.

Maia V and Langguth A (1981) New karyotypes of Brazilian Akodont rodents with notes on taxonomy. Mamm Biol 46:241-249.

McKenna MC and Bell SK (1997) Classification of Mammals Above the Species Level. Columbia University Press, New York, $631 \mathrm{pp}$.

Moojen J (1952) Os Roedores do Brasil. Instituto Nacional do Livro e Biblioteca Científica Brasileira, Rio de Janeiro, $214 \mathrm{pp}$.

Musser GG and Carleton MD (2005) Superfamily Muroidea. In: Wilson DE and Reeder DM (eds) Mammal Species of the World: A Taxonomic and Geographic Reference. 3rd edition. The Johns Hopkins University Press, Baltimore, pp 894-1531.

Nowak RM (1999) Walker's Mammals of the World. v. 2. 6th edition. Johns Hopkins University Press, Baltimore, 1936 pp. 
Ochoa GL, Aguilera M, Pacheco V and Soriano OJ (2001) A new species of Aepeomys Thomas, 1898 (Rodentia, Muridae) from the Andes of Venezuela. Mamm Biol 66:228-237.

Ojeda AA, Ríos CA and Gallardo MH (2004) Chromosomal characterization of Irenomys tarsalis (Rodentia, Cricetidae, Sigmodontinae). Mastozool Neotrop 11:95-98.

Oliveira JA and Bonvicino CR (2002) A new species of sigmodontine rodent from the Atlantic forest of eastern Brazil. Acta Theriol 47:307-322.

Paresque R, Christoff AU and Fagundes V (2009) Karyology of the Atlantic forest rodent Juliomys (Cricetidae): A new karyotype from southern Brazil. Genet Mol Biol 32:301305 .

Pathack S and Stock AD (1974). The X chromosome of mammals: Karyological homology as revealed by banding techniques. Genetics 78:703-714.

Percequillo AR, Gonçalves PR and Oliveira JA (2004) The rediscovery of Rhagomys rufescens (Thomas, 1886), with a morphological rediscription and comments on its systematic relationships based on morphological and molecular (cytochrome b) characters. Mamm Biol 69:238-257.

Pereira LG, Geise L, Cunha AA and Cerqueira R (2008) Abrawayaomys ruschii Cunha \& Cruz, 1979 (Rodentia, Cricetidae) no Estado do Rio de Janeiro, Brasil. Pap Avulsos Zool 48:33-40 (Abstract in English).

Pinheiro PS, Hartmann PA and Geise L (2004) New records of Rhagomys rufescens (Thomas 1886) (Rodentia, Muridae, Sigmodontinae) in Atlantic forest of southeastern Brazil. Zootaxa 431:1-11.

Reig OA (1980) A new fossil genus of South American cricetid rodents allied to Wiedomys, with an assessment of the Sigmodontinae. J Zool 192:257-281.

Reig OA (1984) Distribuição geográfica e história evolutiva dos roedores muroideos Sulamericanos (Cricetidae, Sigmodontinae). Braz J Genet 8:333-365.

Salazar-Bravo J and Yates TL (2007) A new species of Thomasomys (Cricetidae, Sigmodontinae) from central Bolivia. In: Kelt DA, Lessa EP, Salazar-Bravo J and Patton JL (eds) The Quintessential Naturalist: Honoring the Life and Legacy of Oliver P. Pearson. University of California Publications in Zoology, Berkeley, pp 747-774.

Santos N, Fagundes V, Yonenaga-Yassuda Y and Souza MJ (2001) Comparative karyology of Brazilian vampire bats Desmodus rotundus and Diphylla ecaudata (Phyllostomidae, Chiroptera): Banding patterns, base-specific fluorochromes and FISH of ribosomal genes. Hereditas 134:189194.

Sbalqueiro IJ, Mattevi MS, Oliveira LFB and Solano MJV (1991) B chromosome system in populations of Oryzomys flavescens (Rodentia, Cricetidae) from southern Brazil. Acta Theriol 36:193-199.

Sbalqueiro IJ and Nascimento AP (1996) Occurrence of Akodon cursor (Rodentia, Cricetidae) whith 14, 15 and 16 chromosome cytotypes in the same geographic area in southern Brazil. Braz J Genet 19:565-569.

Schmid M (1982) Chromosome banding in Amphibia. VII. Analysis of the structure and variability of NORs in Anura. Chromosoma 87:327-444.

Schweizer D (1976) Reverse fluorescent chromosome banding with chromomycin an DAPI. Chromosoma 58:307-324.

Seabright M (1971) A rapid technique for human chromosomes. Lancet 2:971-972.
Silva MJJ and Yonenaga-Yassuda Y (1999) Autossomal and sex chromossomal polymorphisms with multiple rearrangements and a new karyotype in the genus Rhipidomys (Sigmodontinae, Rodentia). Hereditas 131:211-220.

Smith MF and Patton JL (1999) Phylogenetic relationships and the radiation of sigmodontine rodents in South America: Evidence from cytochrome b. J Mammal 6:89-128.

Spotorno AE, Walker LI, Flores SV, Yevenes M, Marín JC and Zuleta C (2001) Evolución de los filotinos (Rodentia, Muridae) en los Andes del Sur. Rev Chil Hist Nat 74:151-166.

Steiner-Souza F, Cordeiro-Estrela P, Percequillo AR, Testoni AF and Althoff SL (2008) New records of Rhagomys rufescens (Rodentia, Sigmodontinae) in the Atlantic forest of Brazil. Zootaxa 1824:28-34.

Steppan SJ (1995) Revision of the tribe Phyllotini (Rodentia, Sigmodontinae), with a phylogenetic hypothesis for the Sigmodontinae. Fieldiana Zool 80:1-112.

Sumner AT (1972) A simple technique for demonstrating centromeric heterochromatin. Exp Cell Res 75:304-306.

Svartman M and Almeida EJC (1993) Pericentric inversion and X chromosome polymorphism in Rhipidomys sp. (Cricetidae, Rodentia) from Brazil. Caryologia 46:219-225.

Thomas O (1917) On small mammals from the Delta of the Parana. Ann Mag Nat Hist 8:96-97.

Villalpando G, Vargas J and Salazar-Bravo J (2006) First record of Rhagomys (Mammalia, Sigmodontinae) in Bolivia. Mastozool Neotrop 13:43-149.

Voss RS (1993) A revision of the Brazilian muroid rodent genus Delomys with remarks on "Thomasomyine" characters. Am Mus Novit 3073:1-44.

Zanchin NIT, Langguth A and Mattevi MS (1992a) Karyotypes of Brazilian species of Rhipidomys (Rodentia, Cricetidae). J Mammal 73:120-122.

Zanchin NIT, Sbalqueiro IJ, Langguth A, Bossle RC, Castro EC, Oliveira LFB and Mattevi MS (1992b) Karyotype and species diversity of genus Delomys (Rodentia, Cricetidae) in Brazil. Acta Theriol 37:163-169.

\section{Internet Resources}

Metzger JP, Alves LF, Pardini R, Dixo M, Nogueira AA, Negrão MFF, Montesen AC and Catharino ELM (2006) Características ecológicas e implicações para a conservação da Reserva Florestal do Morro Grande. Biota Neotrop 6, http://www.biotaneotropica.org.br/v6n2/pt/abstract?article+bn01006022006 (February 24, 2010).

Pacheco VR (2003) Phylogenetic analyses of the Thomasomyini (Muroidea, Sigmodontinae) based on morphological data. $\mathrm{PhD}$. Thesis, The City University of New York, New York.

https://sites.google.com/site/departamentodemastozoologia/publ icaciones (February 24, 2010).

Pardini R and Umetsu F (2006) Pequenos mamíferos não-voadores da Reserva Florestal do Morro Grande - Distribuição das espécies e da diversidade em uma area de Mata Atlântica. Biota Neotrop 6, http://www.biotaneotropica.org.br/v6n2/pt/abstract?article+bn01006022006 (February 24, 2010).

Associate Editor: Yatiyo Yonenaga-Yassuda

License information: This is an open-access article distributed under the terms of the Creative Commons Attribution License, which permits unrestricted use, distribution, and reproduction in any medium, provided the original work is properly cited. 